\title{
Evaluate Students' Perceptions of the Virtual Learning Environment at Paisley University
}

\author{
http://dx.doi.org/ijet.v6i3.1489 \\ M.M. Abbad ${ }^{1}$ and M. Albarghouthi ${ }^{2}$ \\ ${ }^{1}$ PMU University, Dammam, Saudi Arabia \\ ${ }^{2}$ The University of west of Scotland, Glasgow, United Kingdom
}

\begin{abstract}
The number of students studying online has been significantly increased. This has brought an interest and encouragement to some researchers to examine and evaluate the values perceived from the online learning, and why these vast amounts of students are joining the online learning. The purpose of this study is to evaluate the students' perception of the e-learning system at Paisley University. This study evaluates several factors influencing the perceptions of the undergraduate students who undertaken the information management course. The outcome of this study shows that online students perceived the values of the elearning system differently. Additionally, the factors that mentioned in the literature review affect the students' perceptions of the e-learning system.
\end{abstract}

Index Terms-E-learning, Paisley University, Perceptions, Virtual Learning Environment.

\section{INTRODUCTION}

The radical improvements in new technologies during the last two decades such as multimedia capable computers have increased the power of the technology that is combined with cost reduction. For example, [1] stated that "every eighteen months, you get twice as much power for the same price". Moreover, because the fast growth of the internet it became the dominant global computing network which has resulted in "enthusiastic claims for technology's ability to provide high-quality education for all" [2].

The emergence of electronic learning (e-learning) has developed a new way in training delivery, and this revolution in technology provided opportunities that improved and changed the learning experience for both student and teacher [3]. The capability of the world wide web of integrating huge varieties of multimedia format such as text, audio and video, and provide several means of real-time communications and asynchronous interaction [4]. This great mixture of factors has grabbed the attention of many investors and entrepreneurs to look at the online learning as a market area of the future.

The importance of the e-learning has stretched to concentrate at different sectors such as the public sector, as well as the private sector as a work-past training. In addition, e-learning now is expanding dramatically to reach different educational levels such as school projects and post-secondary level. Today, e-learning is thriving rapidly and operating in different subject's areas, and more or less at all educational studies, institutions, and systems. Elearning illustrates well the relationship between the technological usage and the need to re-organise to maximise its benefits. It also "illustrates the capacity to reach new target groups and to expand the range of educational pro- visions, through the use of technology, when properly organised and structured" [5]. Universities should be able to evaluate e-learning because this will help them to design the e-courses that will enable both the students and the universities to adopt e-learning systems in the future. Because of that, this study will help the e-learning providers to design and to take the students' perceptions in consideration for future developments.

\section{E-LEARNING AT PAISLEY UNIVERSITY}

The University of Paisley has developed Virtual Learning Environment (VLE) for its distant learning courses in order to enable its student to fully engage in the internet programs that are relevant to their study. In addition the information communication technology (ICT) has been used by the university to provide significant communication between university students and the tutors in order to allow the students to interact effectively with the online services. The following services are provided by both systems: E-mail, Online classroom forums, the course information and materials, Different material formats, online campus, and online discussions.

\section{FACTORS ON E-LEARNING SYSTEM THAT INFLUENCE THE STUDENT'S PERCEPTION}

Different factors influence the student's perception of eleaning system. According to the literature, eight factors of e- learning were widely identified as essential to effect the student's perception of e-learning system and good practice. These factors were: Enhancement, Ease of use, Technical support, Flexibility, Usefulness, Teacher effectiveness, Motivation, and Age and Gender. In this section we will summaries the main factors that are exist in the literature.

\section{A. Enhancement}

[6] describe e-learning as an active learning that involves "instructional activities involving students in doing things and thinking about what they are doing". The interactivity provided by e- learning tools has enhanced the learning environment by enabling students to engage actively with the online material. This in turns enhance the students understanding as well as their knowledge [7]. The scenarios and authentic situations that the students encountered in e-learning can enhance their motivation and encourage them for learning and also improve their thinking [8]. Both online instruction and technology have simplified learning by allowing real-life contexts in order to involve students in dealing with problems successfully [9]. Additionally, the online instruction has forced students into a learning experience, rapidly increasing their 
involvements, and producing activities that dramatically allow students to examine and analyze information while building their knowledge [10].

\section{B. Ease of Use}

[11] defines ease of use as "the degree to which a person believes using a particular system would be free of effort". Many studies report that users often rush in choosing and using technologies, and their attitudes in using the technology are effected by the norms, and culture [12]. [13] report that users more often accepted technological applications if their perceptions about them are easier to use than other technologies. [17] report that in the elearning environment, both teachers and students must be familiar with the software tools, the easier they are the more satisfaction will be gained.

\section{Technical support}

The definition of the technical support backed to [14] as "Knowledge people assisting the uses of computer hardware and software products". Many research studies report that the technology use is one of the key factors that influencing the students' satisfaction of the e-learning system. [15] stated that learners became frustrated when encountering technical problems such as communication failures or when they deal with incompatible software during their study. Furthermore, [16] stated that training is critical to the students' satisfaction, as the majority of students show higher satisfaction with their e-learning courses when they received sufficient training in how to use the technology.

\section{Time and space flexibility}

Flexibility is considered one of the most factors that has a great influence on the learners' perception. The majority of students enrolled in e-learning because of its flexibility [18]. However, the term flexibility in e-learning doesn't mean that the deadline for any given course is unlimited, but it refers to the flexible usage for exams/quizzes deadline. The flexibility of e-learning gives many learners the opportunity to continue their education despite their families or careers commitments. With the help of the asynchronous communication tools, learners can easy access the content of their courses, and collaborate with their classmates and instructors at all times [19]. Furthermore, the time flexibility in e-learning encourages many students to formulate their responses and express/share their opinions with their instructors or classmates through online conference or chat room [20].

\section{E. Usefulness}

[11] defined usefulness as "the degree to which a person believes using a particular system would enhance his or her job performance". Many research studies suggest that online discussion improves the students' critical thinking by giving them sufficient time in online conference to process their thinking [9]. In addition, many researchers indicate that, students who enrolled in e- learning courses are more likely to produce accurate results and solutions than students who enrolled in traditional learning [21].

\section{F. Teacher Effectiveness}

[22] identified five factors that 'travel' across context and cultures. These are: "A controlled environment", "A strong commitment to academic goals", "High time on task", "Good teacher-teacher relationships", and "Highly interactive classroom teaching in which there is a balance of control- autonomy for pupils".

[23] stated that the majority of the students come to the website with some ideas on how to use the website. They expect it to be easy to understand and navigate through it readily. [24] points out that "adult learners may be at different levels of self-direction in different situations. They require different kinds of intervention from their teachers at these different stages". Teacher's high expectations are reflected, not just in the tasks they give students, but also in the way they communicate with their students. Students do better when they feel that teachers believe that they can be high achievers". [2] reported that "effective online teaching occurs when the teacher is able to align the technology to a deep and continuously tested understanding of the actual students' experiences, in context".

\section{G. Motivation and Control}

Several researches have indicated that e-learning students need substantial motivation and control in order to achieve their learning goals [25]. [26] concluded that "the technology involved is not nearly as important as other factors, such as learning tasks, learner characteristics, student motivation and the instructor". [27, 28] suggested that motivation is one of the factors that affect online student learning performance. Several researchers have indicated that learning environment needs vast amount of motivation and self-control $[29,30]$.

\section{H. Age and Gender}

[31,32] suggested that men are much more likely than women to have access and to use home computers, and this has been confirmed by more recent North American studies. [33] stated that the online environment is apparently not attractive enough for either gender. [34] Indicated that "men's technology usage decisions are more strongly influenced by perceptions of usefulness. In contrast, women are more influenced by perceptions of ease of use. Men and women focus on different aspects of using computers". [35] mentioned that female students are less likely to use technology than male students; however, male students in their research are more negative than female students towards the e-learning system.

\section{DATA ANALYSIS}

\section{A. The Questionnaire Sample}

This study evaluates several factors influencing the perceptions of the undergraduate students who undertaken the information management course and who must use the elearning system to complete the course. In this research study, 134 students voluntarily participated to answer the questionnaire, whereas the total number of the students undertaking the course was 137 students. The average of $(97.8 \%)$ of the student participation indicates that the response rate from the students was sufficient and reflects the significant effort dedicated to the data collection. Several demographic variables were used in this research study such as marital status, sex, age, and occupation. See Table 1 for more details. 134 participants from different sex/gender are included in this sample to determine the relationship between the students' perception of e-learning at Paisley University and the sex/gender of the students. Table 1 indicates that more or less of the participants are 
in the 20-30 years old, male, and have both internet experience and connection.

\section{B. Questionnaire Data Analysis}

SPSS was used determine the relationships between different variables among the groups. For the outcomes, we will try to abstract some of the relations and the connections between the questions. Furthermore, tables and figures will be used to illustrate the statistical information for the questionnaire.

To analyze the influence of the demographic variables such as (age, sex, income, and internet experience) on the students' perception, these variables will be examined against the most common factors such as (enhancement EN ,ease of use EU, flexibility FL, motivation MOT, teacher effectiveness TE, technical support TS, and usefulness US) that are influencing the students' perception of the e-learning system by the use of (analysis of variances (ANOVA), which is a collection of statistical models, techniques and procedures used in order to find out if the samples between two or more groups have the same means [36]. Each of these variables has its own mean scores, a standard deviation, $F$ ratios and the significant of $F$ ratios that are shown in Tables 2, 3, 4 and 5. In this research analysis, the significant of the $F$ ratio will be used to determine the result of the data analysis. A significant of 0.10 will be used to measure the results between factors and demographic variables. The measurement will be as follow:

If the result of the F Sig for any factor is below the 0.10 , this is an indication of significant differences.

If the result of the F Sig for any factor is above the 0.10 , this is indication of no significant differences.

According to the significant of 0.10 , the results in Table 2 show that both male students and female students have no significant sex differences at all factors. The teacher effectiveness factor scores the highest between the other factors for both male and female, whereas the enhancement factor scores the lowest among other factors. In addition, the table shows that the means for female students is higher than means for male student in term of motivation, enhancement and usefulness towards e-learning, whereas the means for male students score the highest on the other factors.

Table 3 indicates that there are no significant age differences between all factors according to the $F$ ratio of 0.10 . Moreover, the usefulness (US) scores the highest regarding the age of the students, whereas the motivation (MOT) scores the lowest among other factors. This indicates that the majority of the students in terms of age believe that the e-learning is as useful tool for their study. Additionally, the results showed that the means for students who are above 40 years have scored the highest between all categories in terms of e-learning enhancement, motivation, teacher effectiveness, and technical support.

Table 4 indicates that there are no significant income differences between all factors according to the $\mathrm{F}$ ratio 0.10 . The enhancement EN scores the highest (0.858) $\mathrm{F}$ Sig between all factors, whereas the usefulness US scores the lowest (0.299). It is obvious from the above findings that the means for students who earned 200 and less than 500 have scored the highest between all categories in terms of e-learning enhancement, ease of use, flexibility and motivation.

\section{Measurements of Students' Perception of E-learning}

In order to pursue the main aim for this research study which is to evaluate the students perception of the elearning system, further measurements were applied to the student's attitudes in term of their perception of e-learning system. 21 liker-type statements were employed in this section, where each participant needs to state his/ her level of disagreement or agreement on the factors that influence their e-learning perception. The type of response format used in this section is 5- point category that used as follow:

$5=$ strongly agree, $4=$ agree, $3=$ normal, $2=$ disagree, and $1=$ strongly disagree.

From both the literature review and the focus group interviews that are conducted with the students at Paisley University, it was obvious that the main factors that effect the students' perception of e-learning are enhancement $(\mathrm{EN})$, ease of use(EU), flexibility (FL), motivation (MOT), teacher effectiveness (TE), and the usefulness (US). Therefore, the 21 liker-type statements are based upon these factors. Table 5, illustrates the 21 statements, and the factors effect the students' perception.

Table 5 shows the mean and standard deviation of the responses from the students on the 21 liker-type statements. In addition, the table shows that highest score for the mean (3.79) is related to the motivation statement "I use the E-learning system to download PowerPoint presentations and lecture notes." At the same time the lowest score for the mean (2.58) is also related to the motivation statement "E-learning discussion forums are motivating me to build-up my knowledge." This contradiction on the results indicates that each factor has different impacts on the students' perception, and each student has different opinion on the impacts of each factor. In order minimize the level of this contradictory between the results and to indentify the most factor that has an impact on the students' perception, the scores for each respondent on all statements will be summed to get a single result for each mean, as shown in Table 6.

It is notable, that both of the usefulness (US) and the ease of use (EU) factors have the highest mean score between all other factors. But in looking at the standard deviation for each factor, it is observed that the usefulness (US) has a lower standard deviation than the ease of use (EU) factor. This makes usefulness is the most factor that effects the student's perception of e-learning system.

The following findings are based on ANOVA statistical analysis:

The means for female students are higher than the means for male students in term of motivation, enhancement and usefulness towards e-learning whereas the means for male students score are the highest on the other factors.

The means scores for student's age category who are above 40 years have scored the highest between all categories in terms of e-learning enhancement, motivation, teacher effectiveness, and technical support.

The means for students' income category who earned 200 and less than 500 have scored the highest between all categories in terms of e-learning enhancement, ease of use, flexibility and motivation.

The scores of the mean for all factors are all over the scale of three, and the majority of the standard deviation 
values show an adequate level of agreement between participants.

Usefulness has the highest mean score between all factors and all factors have no significant differences.

\section{CONCLUSIONS}

According to both the literature review and the focus group interviews that are conducted with the students at Paisley University, the results showed that the main factors that affect the students' perception of e-learning are enhancement, ease of use, flexibility, motivation, role of instructor, and the usefulness. The scores of the mean for all factors are all over the scale of three, and the majority of the standard deviation values show an adequate level of agreement between participants. It was notable, that both of the usefulness and the ease of use factors have the highest mean score between all other factors. This study increases the literature in some factors that influence the learners' adoption of e-learning systems.

The limitations of this research study can be summarized as follow: the research was conducted on one sample which degreases the required outcome. All the participants' responses could be based on their opinions and feelings rather than on facts or evidence. Factors effected the students' perception are vary. Therefore, some other factors may influence the students perception never been considered in this study.

\section{REFERENCES}

[1] Downes, L. and Mui, C. (1998) Unleashing the Killer App - Digital Strategies for Market Dominance, Harvard Business School Press, Boston.

[2] Stevenson, N. (2001) Culture and citizenship: an introduction, pp. 110, In: N. Stevenson (Ed), Culture \& Citizenship (London, Sage).

[3] Sloman, M. (2001) The e-Learning revolution: from proposition to action, Chartered Institute of Personnel \& Development, London.

[4] Mason, R. (1998) Models of online courses, ALN Magazine, 2 (2).

[5] Bates, A. W. (1995) Technology, open learning and distance education - London: Routledge.

[6] Bonwell, C.C. and Eisen, J.A. (1991) Active learning: Creating excitement in the classroom (ASHE-ERIC Higher Education Report No. 1). Washington, DC: George Washington University.

[7] Pallof, R. and Pratt, K. (2003) The Virtual Student: A Profile and Guide to Working with Online Learners.San Francisco, CA: Josey-Bass Publishers.

[8] Quitadamo, I.J. and Brown, A. (2001) 'Effective teaching styles and instructional design for online learning environments'. National Educational Computing Conference, July 25-27, 2001 (Chicago, IL).

[9] Duffy, T. M. and Cunningham, D. J. (1996). Constructivism: Implications for the design and delivery of instruction. In D. H. Jonassen (Ed.), Handbook of research for educational communications and technology. New York: Macmillan.

[10] Driscoll, M. and Carliner, S. (2005) Advanced web-based training strategies. San Francisco: Pfeiffer.

[11] Davis, F.D. (1989) 'Perceived usefulness, perceived ease of use, and user acceptance of information technology.' MIS Quarterly.

[12] Rice, R.E. and Love, G. (1987) 'Electronic emotion: Socioemotional content in a computer mediated communication network' Communication Research, 14(1), 85-105. http://dx.doi.org/10.1177/009365087014001005

[13] Rander, R. and Rothchild, M. (1975) 'On the allocation of effort'. Journal of Economic Theory, 10, 358-376.

[14] Ralph, W. (1991) The art f computer technical support. California: Peachipt Press.

[15] Essex, C. and Cagiltay, K. (2001) 'Evaluating an online course: Feedback from "distressed" students'. Quarterly Review of Distance Education 2 (2001) (3), pp. 233-239.

[16] Song, L. Singleton, E.S, Hill, J.R. and Koh, M.H (2004) 'Improving online learning: Student perceptions of useful and challenging characteristics'. Internet and Higher Education 7, (1), pp. 59-70. http://dx.doi.org/10.1016/j.iheduc.2003.11.003

[17] Jacobson, M. and Levin, J. (1993) Networked learning environments and Hypertext: constructing personal and shared knowledge spaces. Online material retrieved on (06-03-09) from: http://w3.ed.uiuc.edu/tta/papers/j\&l-tel-ed93.html.

[18] Johnston, J., Killon, J. and Omen, J. (2005) 'Student Satisfaction in the Virtual Classroom.' Internet Journal of Allied Health Sciences and Practice 3, (2) 540-580.

[19] Belanger, F. and Jordan, D. H. (2000). Evaluation and implementation of distance learning.

[20] Moore, M. G. and Kearsley, G. (1996) Distance education: A systems view. Belmont, CA: Wadsworth Publishing Company.

[21] Benbunan-Fich, R. and Hiltz, S.R. (1999) 'Educational applications of CMCS: Solving case studies through asynchronous learning networks'. Journal of Computer-Mediated Communication 4, (3).

[22] Reynolds, A. J. (Ed.). (1999) 'Schooling and high-risk populations: The Chicago Longitudinal Study'. Journal of School Psychology, 37(4). Special Issue.

[23] Konx, E. S. (1997) The pedagogy of the web site design, ALN Magazine, 1(2).

[24] Grow, G. (1996). 'Teaching learners to be self-directed: A stage approach'. Adult Education Quarterly, 41(3), 125-149. http://dx.doi.org/10.1177/0001848191041003001

[25] Smart, K. and Cappel, J. (2006) "Students' Perception of Online Learning: A Comparative Study". Journal of Information Technology Education, 5.

[26] Phipps, R. and Merisotis, J. (1999) What's the difference? A review of contemporary research on the effectiveness of distance learning in higher education. A Report from The Institute for Higher Education Policy, April 1999.

[27] Cole, M. S., Field, H. S. and Harris, S. G. (2004) 'Student learning motivation and psychological hardiness: Interactive effects on students' reactions to a management class'. Academy of Management Learning \&Education, 3(1), 64-85. http://dx.doi.org/10.5465/ AMLE.2004.12436819

[28] Ryan, S., Scott, B., Freeman, B. and Patel, D. (2000) The virtual university: The Internet and resource-based learning. UK: Biddles Ltd.

[29] Golladay, R., Prybutok, V. and Huff, R. (2000). 'Critical success factors for the online learner'. Journal of Computer Information Systems, 40(4), 69-71.

[30] Serwatka, J. (2003) 'Assessment in on-line CIS courses'. Journal of Computer Information Systems, 43(3), 16-20.

[31] Kirkwood, A. and Kirkup, G. (1991) 'Access to computing for home-based students'. Studies in Higher Education, 16(2), 199208. http://dx.doi.org/10.1080/03075079112331382984

[32] Ong and Lai, (2004) "Gender differences in perceptions and relationships among dominants of e-learning acceptance". Computers in Human Behavior 22(5), 816-829.

[33] Caspi, A., Chajut, E., and Saporta,K. (2008) "Participation in class and in online discussions: Gender differences". Computer and Education, 50 (3), 718-729. http://dx.doi.org/10.1016/j.compedu. 2006.08.003

[34] Venkatesh, V. and Morris, M.G. (2000) 'Why don't men ever stop to ask for directions? Gender, social influence, and their role in technology acceptance and usage behavior.' MIS Quarterly 24, (1) 115-139. http://dx.doi.org/10.2307/3250981

[35] Keller, C. and Cernerud, L. (2002) 'Students' Perception of Elearning in University Education. Learning.' Media and Technology 27, (1) 55-67. http://dx.doi.org/10.1080/1358165020270105

[36] Hair, J, F., Anderson, R. E., Tatham, R. L. and Black, W.C. (2006). Multivariate Data Analysis. 5th ed. Englewood Cliffs, N.J: Prentice-Hall.

\section{AUTHORS}

M.M. Abbad is with PMU University, Dammam, Saudi Arabia.

M. Albarghouthi is with University of West of Scotland, Glasgow, United Kingdom

Received October $20^{\text {th }}, 2010$. Published as resubmitted by the authors August $2^{\text {nd }}, 2011$. 
REGULAR PAPER

Evaluate Students' PeRCEPTIONS OF THE VIRTUAL LEARNING ENVIRONMENT AT PAISLEy UNIVERSITY

APPENDIX

TABLE I.

QUESTIONNAIRE SAMPLE

\begin{tabular}{|c|c|c|}
\hline Sex & $\begin{array}{c}\text { Number of } \\
\text { Respondents }\end{array}$ & Percentage (\%) \\
\hline Female & 43 & $32.1 \%$ \\
\hline Male & 91 & $67.9 \%$ \\
\hline Age & & $\begin{array}{c}\text { Percentage } \\
(\%)\end{array}$ \\
\hline Under 20 years & 12 & $9.0 \%$ \\
\hline 20- Under 30 years & 98 & $73.1 \%$ \\
\hline 30- Under 40 years & 16 & $11.9 \%$ \\
\hline Above 40 years & 8 & $6.0 \%$ \\
\hline Martial status & & Percentage $(\%)$ \\
\hline Single & 98 & $73.1 \%$ \\
\hline Married & 12 & $9.0 \%$ \\
\hline Others & 24 & $17.9 \%$ \\
\hline Occupation & & $\begin{array}{c}\text { Percentage } \\
(\%)\end{array}$ \\
\hline Full time & 24 & $17.9 \%$ \\
\hline part time & 38 & $28.4 \%$ \\
\hline Not working & 72 & $53.7 \%$ \\
\hline Home Internet connection availability & & $\begin{array}{c}\text { Percentage } \\
(\%)\end{array}$ \\
\hline Yes & 130 & $97.06 \%$ \\
\hline No & 4 & $2.94 \%$ \\
\hline Monthly income & & Percentage $(\%)$ \\
\hline Less than $£ 200$ & 39 & $29.1 \%$ \\
\hline 200 - less than $£ 500$ & 55 & $41.0 \%$ \\
\hline 500 - less than $£ 800$ & 24 & $17.9 \%$ \\
\hline Above£ 800 & 16 & $12.0 \%$ \\
\hline Internet experience & & Percentage (\%) \\
\hline Never & 0 & $0.0 \%$ \\
\hline Less than 1 year & 0 & $0.0 \%$ \\
\hline $1-2$ years & 0 & $0.0 \%$ \\
\hline More than 2 years & 134 & $100 \%$ \\
\hline Weekly Internet Usage & & Percentage $(\%)$ \\
\hline Never & 0 & $0.0 \%$ \\
\hline Once & 0 & $0.0 \%$ \\
\hline $2-3$ times & 0 & $0.0 \%$ \\
\hline More than 3 times & 134 & $100 \%$ \\
\hline
\end{tabular}

TABLE II.

ILLUSTRATES THE STATISTICS TESTING RESULTS FOR SEX PRODUCED BY ANOVA

\begin{tabular}{|c|c|c|c|c|c|c|}
\hline \multirow{2}{*}{ Factor } & \multicolumn{2}{|c|}{ Male } & \multicolumn{2}{|c|}{ Female } & \multicolumn{2}{|c|}{ F Test } \\
\hline & Mean & $S D$ & Mean & $S D$ & F Ratio & F Sig. \\
\hline Enhancement & 2.91 & 0.77 & 3.45 & 0.85 & 3.397 & 0.074 \\
\hline Ease of use & 3.28 & 1.07 & 3.18 & 1.20 & 0.069 & 0.794 \\
\hline Flexibility & 3.23 & 0.99 & 3.09 & 1.28 & 0.136 & 0.714 \\
\hline Motivation & 3.02 & 0.60 & 3.25 & 0.92 & 0.752 & 0.392 \\
\hline Teacher Effectiveness & 3.23 & 1.08 & 3.22 & 1.00 & 0.000 & 0.975 \\
\hline Technical Support & 2.95 & 0.64 & 3.22 & 0.97 & 0.942 & 0.338 \\
\hline Usefulness & 3.17 & 1.10 & 3.42 & 0.94 & 0.419 & 0.521 \\
\hline
\end{tabular}


REGULAR PAPER

Evaluate Students' PercePtions of THE VIRTUAl LEARning ENVIRONMENT AT PAISLEy UNIVERSITY

TABLE III.

ILLUSTRATES THE STATISTICS TESTING RESULTS FOR AGE, PRODUCED BY ANOVA

\begin{tabular}{|l|l|l|l|l|l|l|l|l|l|l|}
\hline \multirow{2}{*}{ Factor } & \multicolumn{2}{|c|}{ Under 20 years } & \multicolumn{2}{c|}{$\mathbf{2 0}$ under-30 years } & \multicolumn{2}{|c|}{ 30 under-40 years } & \multicolumn{2}{c|}{ above 40 years } & \multicolumn{2}{|c|}{ F Test } \\
\cline { 2 - 12 } & Mean & SD & Mean & SD & Mean & SD & Mean & SD & F Ratio & F Sig. \\
\hline Enhancement & 3.16 & 0.57 & 3.02 & 0.89 & 3.12 & 0.47 & 3.75 & 1.06 & 0.468 & 0.707 \\
\hline Ease of use & 3.33 & 1.15 & 3.29 & 1.15 & 3.16 & 1.17 & 2.83 & 1.76 & 0.111 & 0.953 \\
\hline Flexibility & 3.0 & 1.32 & 3.2 & 1.11 & 3.5 & 0.57 & 2.75 & 1.76 & 0.235 & 0.872 \\
\hline Motivation & 2.66 & 0.80 & 3.14 & 0.76 & 3.0 & 0.28 & 3.4 & 0.56 & 0.518 & 0.673 \\
\hline $\begin{array}{l}\text { Teacher Effec- } \\
\text { tiveness }\end{array}$ & 3.50 & 1.00 & 3.14 & 1.11 & 3.50 & 1.0 & 3.50 & 0.70 & 0.243 & 0.865 \\
\hline $\begin{array}{l}\text { Technical Sup- } \\
\text { port }\end{array}$ & 3.25 & 1.00 & 2.98 & 2.98 & 3.18 & 0.37 & 3.25 & 1.06 & 0.213 & 0.887 \\
\hline Usefulness & 3.44 & 0.83 & 3.2 & 1.09 & 3.41 & 0.78 & 3.33 & 1.88 & 0.84 & 0.968 \\
\hline
\end{tabular}

TABLE IV.

ILLUSTRATES THE STATISTICS TESTING RESULTS FOR INCOME, PRODUCED BY ANOVA

\begin{tabular}{|c|c|c|c|c|c|c|c|c|c|c|}
\hline \multirow{2}{*}{ Factor } & \multicolumn{2}{|c|}{ Less than $£ 200$} & \multicolumn{2}{|c|}{200 - less than $£ 500$} & \multicolumn{2}{|c|}{500 - less than $£ 800$} & \multicolumn{2}{|c|}{ Above£ 800} & \multicolumn{2}{|c|}{ F Test } \\
\hline & Mean & $S D$ & Mean & $S D$ & Mean & $S D$ & Mean & $S D$ & F Ratio & F Sig. \\
\hline Enhancement & 2.95 & 0.89 & 3.21 & 0.82 & 3.08 & 0.73 & 3.0 & 1.08 & 0.199 & 0.858 \\
\hline Ease of use & 3.16 & 0.89 & 3.5 & 1.23 & 2.83 & 1.34 & 3.25 & 0.83 & 0.519 & 0.672 \\
\hline Flexibility & 3.15 & 1.05 & 3.42 & 0.93 & 2.91 & 1.42 & 2.87 & 1.31 & 0.449 & 0.719 \\
\hline Motivation & 3.1 & 0.71 & 3.21 & 0.84 & 2.8 & 0.53 & 3.15 & 0.5 & 0.453 & 0.716 \\
\hline $\begin{array}{l}\text { Teacher Effec- } \\
\text { tiveness }\end{array}$ & 3.25 & 0.67 & 3.07 & 1.29 & 3.75 & 1.08 & 3.0 & 0.81 & 0.645 & 0.592 \\
\hline $\begin{array}{l}\text { Technical Sup- } \\
\text { port }\end{array}$ & 3.3 & 0.57 & 2.98 & 0.91 & 2.87 & 0.64 & 2.87 & 0.85 & 0.550 & 0.651 \\
\hline Usefulness & 3.0 & 0.90 & 3.66 & 1.04 & 2.88 & 1.04 & 3.0 & 1.27 & 1.28 & 0.299 \\
\hline
\end{tabular}

TABLE V.

STATEMENTS REFLECT FACTORS IMPACT ON STUDENTS’ PERCEPTION

\begin{tabular}{|c|c|c|c|}
\hline Factor & Statement & Mean & SD \\
\hline \multirow[t]{2}{*}{ Flexibility } & The E-learning system is flexible & 3.17 & 1.35 \\
\hline & I am using the E-learning system at any place and at any time & 3.20 & 1.22 \\
\hline \multirow{4}{*}{$\begin{array}{l}\text { Technical Sup- } \\
\text { port }\end{array}$} & There is a training course in the use of the E-learning system & 2.88 & 1.03 \\
\hline & I don't have difficulty accessing the E-learning system & 2.97 & 1.50 \\
\hline & E-learning modules are usually updated on a weekly basis & 3.26 & 1.08 \\
\hline & The E-learning support group solve technical problems efficiently & 3.05 & 0.77 \\
\hline \multirow[t]{2}{*}{ Enhancement } & E-learning enhances the face-to-face learning experience & 3.00 & 1.10 \\
\hline & E-learning complements the face-to-face learning experience & 3.17 & 0.93 \\
\hline \multirow[t]{3}{*}{ Ease of Use } & Navigation through the E-learning system is easy & 3.26 & 1.21 \\
\hline & It is easy to find what I want on the e-learning system & 3.20 & 1.17 \\
\hline & Overall, the E-learning system is easy to use & 3.29 & 1.21 \\
\hline \multirow[t]{3}{*}{ Usefulness } & E-learning allows me to provide feedback to my lecturers and teachers & 3.20 & 1.14 \\
\hline & E-learning is a useful tool that includes information I might need for my studies & 3.35 & 1.36 \\
\hline & Overall, the E-learning system is useful & 3.20 & 1.29 \\
\hline \multirow[t]{5}{*}{ Motivation } & E-learning discussion forums are motivating me to build-up my knowledge & 2.58 & 1.18 \\
\hline & $\begin{array}{l}\text { Quizzes posted on the E-learning system are motivating me to check my course under- } \\
\text { standing }\end{array}$ & 2.64 & 1.22 \\
\hline & I use the E-learning system to download PowerPoint presentations and lecture notes & 3.79 & 1.24 \\
\hline & I think E-learning resource tools mostly have enhanced my learning process & 3.32 & 1.19 \\
\hline & I think the library has mostly enhanced my learning process & 3.14 & 1.13 \\
\hline \multirow{2}{*}{$\begin{array}{l}\text { Teacher effec- } \\
\text { tiveness }\end{array}$} & I usually get feedback from my instructor & 3.20 & 1.09 \\
\hline & My instructor usually motivates students to use the E-learning system & 3.26 & 1.26 \\
\hline
\end{tabular}


REGULAR PAPER

Evaluate Students' PercePtions of THE VIRTUAl LEARning ENVIRONMENT AT PAISLEy UNIVERSITY

TABLE VI.

ILLUSTRATES THE TOTAL MEANS FOR EACH FACTOR THAT INFLUENCE THE STUDENT'S PERCEPTION

\begin{tabular}{|l|l|l|}
\hline \multicolumn{1}{|c|}{ Factor } & \multicolumn{1}{c|}{ Mean } & \multicolumn{1}{c|}{ (SD) } \\
\hline Enhancement & 3.08 & 0.83 \\
\hline Ease of use & 3.25 & 1.10 \\
\hline Flexibility & 3.19 & 1.08 \\
\hline Motivation & 3.10 & 0.71 \\
\hline Teacher effectiveness & 3.23 & 1.04 \\
\hline Technical support & 3.04 & 0.75 \\
\hline Usefulness & 3.25 & 1.04 \\
\hline
\end{tabular}

